\title{
Filozofia umysłu - początek czy koniec?
}

Józef Bremer, Wprowadzenie do filozofii umystu, Wydawnictwo WAM, Kraków 2010, ss. 255.

„Czym jest owo umysłowe «coś», do którego odnoszą się terminy: «myśli», «pragnie», «odczuwa ból»?"1. Tymi słowami Józef Bremer, autor książki Wprowadzenie do filozofii umystu zachęca nas do poznania „nowych” obiektów refleksji filozoficznej, do jakich należy problem umysł-ciało. Dlaczego już na wstępie mojej recenzji używam cudzysłowu przy słowie „nowych”? Odpowiedź nasunie się czytelnikowi po kilku stronach lektury. Prezentowany przez Bremera problem nie jest prekursorski. Już od czasów starożytnych ludzie zastanawiali się nad zasadą funkcjonowania naszych myśli i stanów emocjonalnych, a od Oświecenia problem relacji umysł - ciało, stał się jednym z kluczowych zagadnień filozoficznych. Rzetelne przygotowanie treści książki Bremer zawdzięcza z pewnością swoim długoletnim studiom nad prezentowanym problemem. Jako doktor habilitowany, wykładowca Wyższej Szkoły Filozoficzno-Pedagogicznej „Ignatianum”, Profesor w Instytucie Filozoficznym Uniwersytetu Jagielońskiego oraz kierownik Zakładu Kogniwistyki tegoż Uniwersytetu, autor Wprowadzenia do filozofii umystu jest niewątpliwie bardzo wiarygodnym źródłem informacji. Należy jeszcze wspomnieć, że w roku 2001 Bremer przebywal jako visiting scholar na Univerity of Arizona-Center for Consciousness Studies, gdzie rozwijał swoją wiedzę na temat prezentowanego zagadnienia. Czego można więcej żądać od książki poruszającej filozoficzne zagadnienia? Autor, rzetelnie opisujaccy niezwykle ciekawy temat, to bez wattpienia jeden z kluczowych argumentów przemawiających za wyborem

${ }^{1}$ J. Bremer, Wprowadzenie do filozofii umystu, WAM, Kraków 2010, s. 9. 
konkretnej książki. Ponadto, książka Bremera jest „wprowadzeniem”, o czym informuje sam autor: „Moje opracowanie powstało z myślą o dwóch grupach czytelników: o studentach filozofii i psychologii, a także kognitywistyki, oraz o czytelnikach mniej zaznajomionych z filozoficzno-analitycznym rodzajem argumentacji”' ${ }^{2}$. Nie trzeba być filozofem by podjąć wyzwanie myślenia nad: „,jednym z najtrudniejszych pytań filozoficznych i naukowych"3, jakim jest np. konstytucja ludzkiej świadomości, problem qualiów, oddziaływanie umysł - ciało czy redukcjonizm materialistyczny, ale trzeba być „świadomym" swojego istnienia i kroczyć przez życie rozwiązując kolejne zawiłości jakie stwarza stechnicyzowany świat.

Wstępnie można powiedzieć, że historia filozofii dostarcza nam dwóch ,standardowych" rozwiązań problemu umysł - ciało: dualistycznego i monistycznego. Monizm może być materialistyczny (tylko materia jest działającą substancją) lub spirytualistyczny (tylko duch, umysł jest działającą substancją) ${ }^{4}$.

Koncepcja monizmu materialistycznego jest główną interpretacją problemu umysł - ciało, którą autor próbuje nam przybliżyć w swoim „wprowadzeniu". Oczywiście pierwsze dwa rozdziały stanowią swoiste kompendium wiedzy na temat dualizmu oraz materializmu, co ma na celu przybliżenie ogólnych pojęć i problemów, rozważanych następnie w perspektywie monizmu materialistycznego. Tak oto Józef Bremer przedstawia arystotelesowskie rozumienie psyche-physis odwołując się do pojęcia duszy, które Stagiryta uważa za zasadę i element podstawowy w jedności umysłowocielesnej wszystkich poruszających się (żyjących) istot. Następnie ukazuje mechanicystyczne rozumienie ciała i całkowitą odrębność res cogitans od res extensa w dualistycznej filozofii Kartezjusza oraz współczesny dualizm J. Ecclesa, mówiący o ewolucji świadomości. Ważną rolę odgrywa, według Bremera, filozofia szkoły

\footnotetext{
2 Tamże, s. 18 .

3 Tamże.

4 Tamże, s. 14.
} 
wiedeńskiej reprezentowanej przez Ludwiga Wittgensteina, który zjawiska umysłowe, uważa za tak subiektywne, że zasadnym jest mówienie o pewnej „grze językowej”, której efektem są owe pojęcia zjawisk mentalnych.

Po obszernym (dwurozdziałowym) wstępie i zarysowaniu problematyki rozgrywającej się na przestrzeni wieków, Bremer może spokojnie przejść w swoich rozważaniach do problemu głównego, czyli monizmu materialistycznego. Kolejne rozdziały Wprowadzenia do filozofi umysłu traktują o materializmie redukcjonistycznym i nieredukcjonistycznym. Pierwszy z nich autor rozważa opierając się o teorie behawioryzmu logicznego, teorie identyczności typów, teorie materializmu eliminacyjnego Paula Feyerabend'a, Willarda Van Ormana Quine'a, czy Paula M. Churchland'a, oraz teorie funkcjonalizmu. Tłumacząc zagadnienia materializmu nieredukcjonistycznego Bremer odwołuje się do monizmu anomalnego Davidsona, teorii superweniencji (słabej i mocnej) oraz teorii emergencji.

Ostatnie dwa rozdziały autor poświęca, jak się wydaje, najbardziej kontrowersyjnym zagadnieniom, mianowicie wolnej woli oraz świadomości. Czy determinizm jest w naszym życiu tak silny, że brak jest miejsca na oznaki wolnej woli? Ten problem jest rozważany przez Bremera w perspektywie eksperymentów Libeta, Haggarda oraz Eimera. Czym są qualia i jaką rolę odgrywają w świadomości ludzkiej? Argument z zombi, a także neuronaukowa naturalizacja świadomości Cricka i Kocha są próbą odpowiedzi autora na zadane pytanie.

Podział rozdziałów w których dokonuje się wieloaspektowe rozważanie problemu umysł - ciało, może początkowo wprowadzić czytelnika w zakłopotanie. Nagromadzenie nazwisk także nie sprzyja łatwemu odbiorowi książki Bremera. Zaskakujący pozostaje jednak fakt, że pozorny chaos, jaki tworzył się w mojej głowie, został rozwiany praktycznie tuż po zakończeniu lektury, a świadomy namysł nad sposobem zaprezentowania wprowadzenia w tema- 
tykę filozofii umysłu, ukazał dużą roztropność autora w doborze poszczególnych zagadnień.

Najważniejszym argumentem, przemawiającym za książką Józefa Bremera, pozostaje chyba właśnie to, że ma ona charakter wprowadzenia. Dla czytelnika, który nigdy nie zetknął się z teoriami filozofii umysłu, książka ta stanowi pewnego rodzaju kompendium wiedzy, którego przyswojenie jest bardzo pomocne w dalszym zgłębianiu zagadnienia relacji umysł - ciało. Jak możemy łatwo wywnioskować, na wielu uniwersytetach na świecie, jest to problem wiodący. Tworzy się zakłady kognitywistyki, mające na celu poszukiwanie odpowiedzi na pytania o świadomość, mentalność i fizykalność człowieka. Nauki szczegółowe, takie jak fizyka, chemia, czy biologia są włączane w problemy filozoficzne, dla ,,jaśniejszego" i „wyraźniejszego" ukazania problemu. Coraz większą rolę, za sprawą Wittgensteina i wcześniejszych, odgrywa logika, panująca $\mathrm{w}$ analitycznej filozofii. Pozostaje jednak pytanie, czym jest filozofia - pytaniem o to, ,jaki” jestem, „po co" jestem? Moim zdaniem takie ujęcie filozofii, jakie prezentuje w swojej książce Bremer wyklucza teleologiczność, a także czyni nasz życie bezsensownym. Co może dać mi znalezienie odpowiedzi na pytanie, w jaki sposób funkcjonują qualia, czy ile milisekund potrzeba do świadomego powstrzymania pewnych czynności, zapoczątkowanych jako pozornie nieświadome? Pozytywizm umarł w filozofii praktycznie wraz ze śmiercią Comte'a, ale nie umarł w ludzkim myśleniu. Technicyzacja i konsumpcjonizm sa przyczynami rozleniwienia umysłowego. Nad zagadnieniami prezentowanymi przez filozofię umysłu „prości” ludzie nie mają „czasu” myśleć. Tym bardziej nie mają chęci. Prowadzi to do powstania elitarnych grup, filozofów, którzy uważają, że opisując zagadnienia problemu umysł - ciało, rozwiązują największą zagadkę ludzkości i być może tak też się dzieje. Tylko kto z tego rozwiązania będzie korzystał, gdy przez technicyzację i wygodnictwo, poziom intelektualny osiągnie opłakane rezultaty? Pewnie nikt. Powracając do pytania o sens, swoistą teleologię, której, moim zdaniem filozofia została pozbawiona (przede wszystkim 
przez swą ,szczegółowość” w naukach kognitywnych) należy spytać, dlaczego Arystoteles czy Kartezjusz, których poglądy były prezentowane przez Bremera, wykraczają poza moje odczucia związane z ateleologicznością i generalizowalną szczegółowością filozofii umysłu? Odpowiedz jest jedna. Za tymi filozofami stoi system, który stworzyli oni w oparciu o człowieka i jego relację umysł - ciało, system, który był teleologiczny, który dawał nadzieje na jutro. Jedynym zadaniem, jakie stoi teraz przed naukami kognitywnymi, jest zbudowanie systemu, będącego obrazem naszych czasów oraz nadającego sens życiu ludzkiemu. Od powodzenia tego przedsięwzięcia może zależeć nasza przyszłość.

Muszę przyznać, że książki wydawane w serii „Myśli filozoficznej” wydawnictwa WAM, są ciekawą propozycją. Wprowadzenie do filozofii umysłu Józefa Bremera, potwierdza moje przekonanie. Dokładność w doborze tematów daje czytelnikowi ogólny ogląd filozoficzny na wiele problemów, dlatego mogę z wielką przyjemnością polecić wszystkim zainteresowanym tę pozycję. Omówienie poszczególnych zagadnień w obrębie koncepcji monizmu materialistycznego w filozofii umysłu, stwarza możliwość zajęcia się tym problemem dokładniej, a obfita lista autorów, do których odsyła Bremer pozwala nie ustawać w poszukiwaniach różnych interpretacji. Czy filozofia umysłu jest odpowiedzią na problemy dzisiejszego świata? Wydaje się, że jeszcze daleka droga czeka tę dziedzinę do osiągnięcia pożądanego skutku. Wiele błędów może zostać popełnionych przez człowieka w drodze do prawdy, ale jak mówi łacińska sentencja: Hominis est errare, insipientis in errore perseverare. Mam nadzieje, że przyszłe pokolenia nie uznają nas za „głupców”, lecz będą czerpać z tego co wypracowaliśmy. 